\title{
Evaluation of calcium ion release in calcium hydroxide prototype as intracanal medicament
}

\author{
Atia N. Sidiqa, ${ }^{1 *}$ Myrna N. Zakaria, ${ }^{2}$ Ira Artilia, ${ }^{1}$ Zwista Y. Dewi, ${ }^{1}$ Arief Cahyanto ${ }^{3}$
}

CrossMark

\section{Abstract}

Objective: Calcium Hydroxide $\left(\mathrm{Ca}(\mathrm{OH})_{2}\right)$ has been widely used in many dental treatments such as pulp capping, dentin hypersensitivity and as an endodontic intracanal medicament. $\mathrm{Ca}(\mathrm{OH})_{2}$ is highly alkaline, has antimicrobial, and remineralization action by releasing $\mathrm{Ca}^{2+}$ and $\mathrm{OH} . \mathrm{Ca}^{2+}$ release plays an important role in cell proliferation and remineralization of hard tissue healing. Indonesian limestone can be synthesized to produce $\mathrm{Ca}(\mathrm{OH})$, that can be an alternative to commercial $\mathrm{Ca}(\mathrm{OH})$, available. Therefore this study aimed to synthesized a $\mathrm{Ca}(\mathrm{OH})$, prototype and evaluate the $\mathrm{Ca}^{2+}$ released by the $\mathrm{Ca}(\mathrm{OH}){ }_{2}$ prototype. Material and Methods: $\mathrm{Ca}(\mathrm{OH})_{2}$, prototype was synthesized from limestone by calcination process and characterized by XRD and FTIR. The $\mathrm{Ca}(\mathrm{OH})_{2}$ prototype was then manipulated to a pasta form by mixing the powder with distilled water in $0.8 \mathrm{w} / \mathrm{p}$ ratio then inserted to a polyethylene tubed $(2 \times 10 \mathrm{~mm})$ using and immersed in $10 \mathrm{ml}$ distilled water. Samples were divided into three groups for different periods of $\mathrm{Ca}^{2+}$ evaluation (1, 7 and 14 days). The $\mathrm{Ca}^{2+}$ concentration released was measured by a Spectrophotometer (DIRUI DR-7000D). Data obtained were analyzed by Anova.

Results: The observations on one day immersion was $3.589 \mathrm{mg} / \mathrm{dL}$, the observation for seven days was $3.736 \mathrm{mg} / \mathrm{dL}$, and for 14 days was $3.850 \mathrm{mg} / \mathrm{dL}$. Statistically $\mathrm{p}<0.05$.

Conclusion: Calcium hydroxide prototype released a sustainable amount of $\mathrm{Ca}^{2+}$ up to 14 days with the highest concentration achieved on day 14 th.
${ }^{1}$ Departement of Dental Materials Science and Technology, Program Study of Dentistry, Faculty of Medicine, Universitas Jenderal Achmad Yani, Cimahi, Indonesia ${ }^{2}$ Departement of Endodontology and Operative Dentistry, Program Study of Dentistry, Faculty of Medicine, Universitas Jenderal Achmad Yani, Cimahi, Indonesia ${ }^{3}$ Departement of Dental Materials Science and Technology, Faculty of Dentistry, Universitas Padjadjaran, Jatinangor, Indonesia

*Correspondence to: Atia N. Sidiqa, Departement of Dental Materials Science and Technology, Program Study of Dentistry, Faculty of Medicine, Universitas Jenderal Achmad Yani, Cimahi, Indonesia atia.nurul@lecture.unjani.ac.id

Received: 5 December 2019 Revised: 10 February 2020 Accepted: 21 July 2020 Available Online: 1 August 2020
Keywords: $\mathrm{Ca}^{2+}$ release, Calcium hydroxide, Limestone

Cite this Article: Sidiqa AN, Zakaria MN, Artilia I, Dewi ZY, Cahyanto A. 2020. Evaluation of calcium ion release in calcium hydroxide prototype as intracanal medicament. Journal of Dentomaxillofacial Science 5(2): 86-89. D0I: 10.15562/jdmfs.v5i2.1017

\section{Introduction}

Root canal infections often occur due to progressive caries. Microorganisms in the root canal system can penetrate to the apical foramen and enter the periapical region resulting in tissue damage and bone resorption. Root canal therapy is a treatment to prevent and control periapical infections. The outcome of this treatment is strongly influenced by the elimination of intracanal microorganisms. ${ }^{1-2}$ $\mathrm{Ca}(\mathrm{OH})_{2}$ has advocated as the most commonly used intracanal medicament disinfection agent. $\mathrm{Ca}(\mathrm{OH})_{2}$ mechanism action is through dissociation of $\mathrm{Ca}^{2+}$ which play an important role in the process of tissue mineralization and $\mathrm{OH}^{-}$ions that elevate the surrounding $\mathrm{pH}$ thus inhibits bacterial growth. $\mathrm{Ca}^{2+}$ ions activate the Transforming Growth Factor type $\beta$ (TGF- $ß$ ) which biomineralization and Adenosine Triphosphate (ATP) which accelerates the process of bone and dentin mineralization. When applied to the root canal as an intracanal medicament, $\mathrm{Ca}(\mathrm{OH})_{2}$ breaks down to $\mathrm{Ca}^{2+}$ and $\mathrm{OH}^{-}$then diffuse through the dentinal tubules and kill the bacteria inside. ${ }^{3,4}$ In general, the diameter of the dentinal tubules is about 1 to $2.5 \mu \mathrm{m}$ which can be penetrated by bacteria such as enterococcus faecalis and other anaerobic bacteria. Therefore, material that can penetrate into dentinal tubules is needed to reach to small and complex sites.
$\mathrm{Ca}(\mathrm{OH})_{2}$ with smaller particle size than dentinal tubules can penetrate into dentinal tubules and work more effectively. ${ }^{4-7}$

Limestone $\left(\mathrm{CaCO}_{3}\right)$ is one of the natural resources in Indonesia. Limestone molecules contain atoms of calcium and oxygen. $\mathrm{CaCO}_{3}$ can transform to calcium oxide $(\mathrm{CaO})$ through calcination process at $900^{\circ} \mathrm{C} . \mathrm{Ca}(\mathrm{OH})_{2}$ paste was produced by dissolving $\mathrm{CaO}$ powder with distilled water for 24 hours. The $\mathrm{Ca}(\mathrm{OH})_{2}$ paste was then dried at $80^{\circ} \mathrm{C}$ to get the final result in the form of $\mathrm{Ca}(\mathrm{OH})_{2}$ powder. In this way, limestone can be utilized in the medical field, such as material research for clinical applications and its development in the manufacture of materials to increase the economic value of limestone itself. ${ }^{8,9}$ The Palimanan limestone has been successfully synthesized and characterized by our previous study, however improvement and in vitro evaluations regarding its physical/mechanical properties is yet to be carried out. $\mathrm{Ca}(\mathrm{OH})_{2}$ can be applied as inter appointment dressing, as well as pulp capping agent, therefore, additional material such as retarders, accelerators, radiopacifier or modification on its particle size must be adjusted according to its clinical application needs. ${ }^{10-12}$

Atomic absorption spectrophotometry can be utilized for qualitative and quantitative analysis. 
Qualitative analysis can analyze organic compounds, while quantitative analysis ensures the quantity of molecules absorbed. The basic mechanism of a spectrophotometer is the light absorption as a beer-lambert law which states that when a beam of light is passed through a transparent cell containing a solution will be absorbed. ${ }^{9}$ A spectrophotometer runs by using a solution and measure the absorbance at the right wavelength. The selected wavelength is usually the maximum absorption wavelength $(\lambda \max )$, if there is a small error in setting the wavelength scale then there is an effect on the absorbance measurement. Ideally, the concentration must be adjusted to absorb it so that the optimal measurement accuracy and accuracy are obtained. ${ }^{12-14}$

Since the release of inorganic ions namely, $\mathrm{Ca}^{2+}$ plays an important task in the effectiveness of dental materials, many studies have been carried out to measure the $\mathrm{Ca}^{2+}$ ions released by different kinds of dental material. ${ }^{15-18}$ Considering the newly developed material has not comprehensively evaluated particularly in its bioactivity by releasing $\mathrm{Ca}^{2+}$ ions, our study aimed to evaluate the $\mathrm{Ca}^{2+}$ release rate of the $\mathrm{Ca}(\mathrm{OH})_{2}$ prototype from Indonesian limestone at different interval of time using an atomic spectrophotometer.

\section{Material and Methods}

Limestone $\left(\mathrm{Ca}(\mathrm{CO})_{3}\right)$ was obtained from Palimanan, Cirebon and used as an alternative raw material for synthesizing $\mathrm{Ca}(\mathrm{OH})_{2}$ as an intraca-nal medication material. The synthesis process to produce $\mathrm{Ca}(\mathrm{OH})_{2}$ includes combustion, grinding, filtering and drying. Firstly $\mathrm{Ca}(\mathrm{CO})_{3}$ was cleaned with distilled water, then calcined for 1 hour with $900^{\circ} \mathrm{C}$, crushed to obtain the powder, and sieved using a 400 mesh sieve to obtain a fine powder. After $\mathrm{CaO}$ powder was obtained, stirring with a magnetic stirrer was carried out at a temperature of $50^{\circ} \mathrm{C}$ for 1 hour then left 24 hours to get the sediment and dried at $80^{\circ} \mathrm{C}$ to produce a $\mathrm{Ca}(\mathrm{OH})_{2}$ prototype. ${ }^{9}$ FTIR analysis was done to characterize the synthesized cement. Moreover, to evaluate the $\mathrm{Ca}^{2+}$ release, the $\mathrm{Ca}(\mathrm{OH})_{2}$ prototype powder was mixed with distilled water to $0,8 \mathrm{w} / \mathrm{p}$ ratio to form a paste consistency as study samples. The $\mathrm{Ca}(\mathrm{OH})_{2}$ paste was inserted into a polyethylene tubed $(2 \times 10 \mathrm{~mm})$ using a plastic syringe and immersed in $10 \mathrm{ml}$ distilled water with a neutral $\mathrm{pH}(7,0)$, and stored at $37^{\circ} \mathrm{C}$ water bath (Schutzart DIN 40050IP 20). Samples were divided into 3 groups $(n=9)$ for different periods of $\mathrm{Ca}^{2+}$ calculation $(1,7$ and 14 days). A spectrophotometer (DIRUI DR-7000D) was used to measure the amount of $\mathrm{Ca}^{2+}$ released.

\section{Results}

FTIR functions to identify functional groups in the sample. The functional group to be identified is $\mathrm{O}, \mathrm{H}$ in the range 4000 to $600 \mathrm{~cm}^{-1}$ as shown in figure 1 .

This figure shows the diffractogram of the calcium hydroxide prototype FTIR characterization. $\mathrm{OH}$ group was detected at wavenumber $3641.6 \mathrm{~cm}^{-1}$ which showed the presence of covalent bonds with the vibration of the $\mathrm{O}-\mathrm{H}$ functional group. The $\mathrm{C}=\mathrm{O}$ bond was also detected at a wavelength of $1845.88 \mathrm{~cm}-1$ and a C-O bond was detected at a wavelength of $1176.58 ; 1082.07 \mathrm{~cm}-1$ which shows there is a group $\mathrm{CO}_{3}{ }^{2-} \cdot{ }^{19}$

The $\mathrm{Ca}^{2+}$ release rate for all tested groups are shown in table 1 . The observations on day 1 immersion was $3.589 \mathrm{mg} / \mathrm{dL}$, day 7 was $3.736 \mathrm{mg} / \mathrm{dL}$, and the observation for day 14 days was $3.850 \mathrm{mg} / \mathrm{dL}$.

The results of statistical analysis using ANOVA test at $95 \%$ confidence level showed significant differences in the $\mathrm{Ca}^{2+}$ ion release rate on observations of immersion for 1 day, 7 days and 14 days with a value of $p=0.033$ (value $p \leq 0,05$ ). The results of further tests using Poshoct test at $95 \%$ confidence level showed that there was a significant difference in the $\mathrm{Ca}^{2+}$ ion release rate of 14 days of immersion compared to 1 day of immersion with a value of $p=0.02(p \leq 0.05)$, whereas there was no significant difference on 7 days immersion observation compared to 1 day immersion with $\mathrm{p}=0.27$ figure 2 .

\section{Discussion}

$\mathrm{Ca}(\mathrm{OH})_{2}$ is an intracanal medicament that has an antimicrobial effect. $\mathrm{Ca}(\mathrm{OH})_{2}$ works by the dissolution $\mathrm{Ca}^{2+}$ and $\mathrm{OH}^{-}$through a solvent vehicle. This dissolution elevates its alkalinity and acts as

Table 1 Mean $\mathrm{Ca}^{2+}$ released of calcium hydroxide prototype

\begin{tabular}{lcc}
\hline Group & $\mathbf{C a}^{2+}$ Ion Release Prototype $(\mathbf{m g} / \mathbf{d L})$ & P-value \\
\hline Day 1 & $3.589 \pm 0.14$ & 0.03 \\
Day 7 & $3.736 \pm 0.22$ & 0.27 \\
Day 14 & \pm 0.18 & $0.02^{*}$ \\
\hline
\end{tabular}

$\mathrm{p}$ value $\leq 0.05$ 


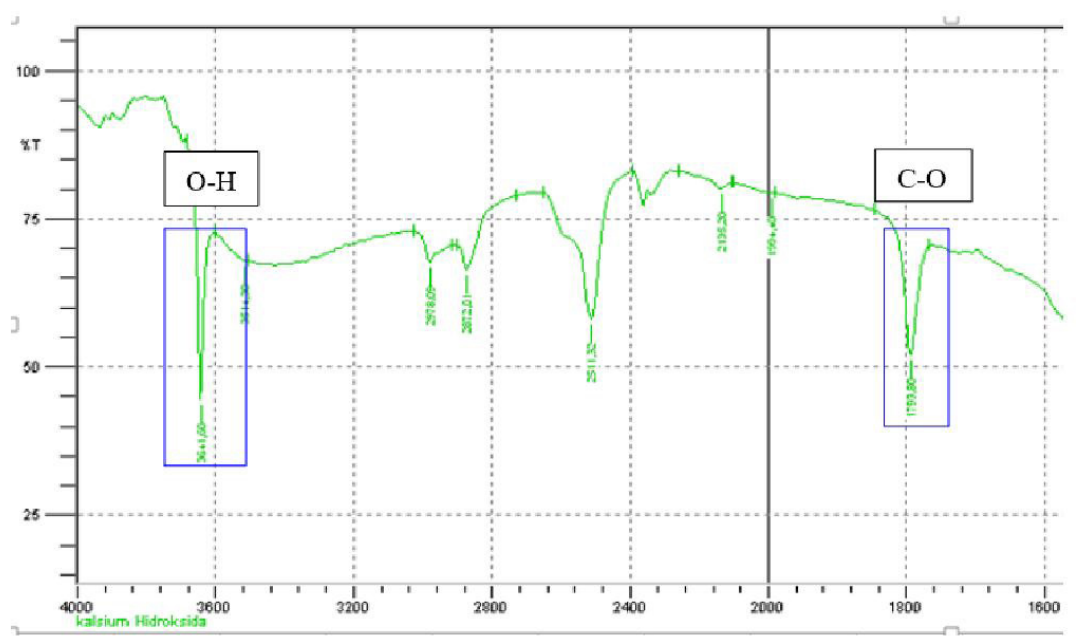

Figure 1 Graph of FTIR Analysis in $\mathrm{Ca}(\mathrm{OH})_{2}$ Prototype

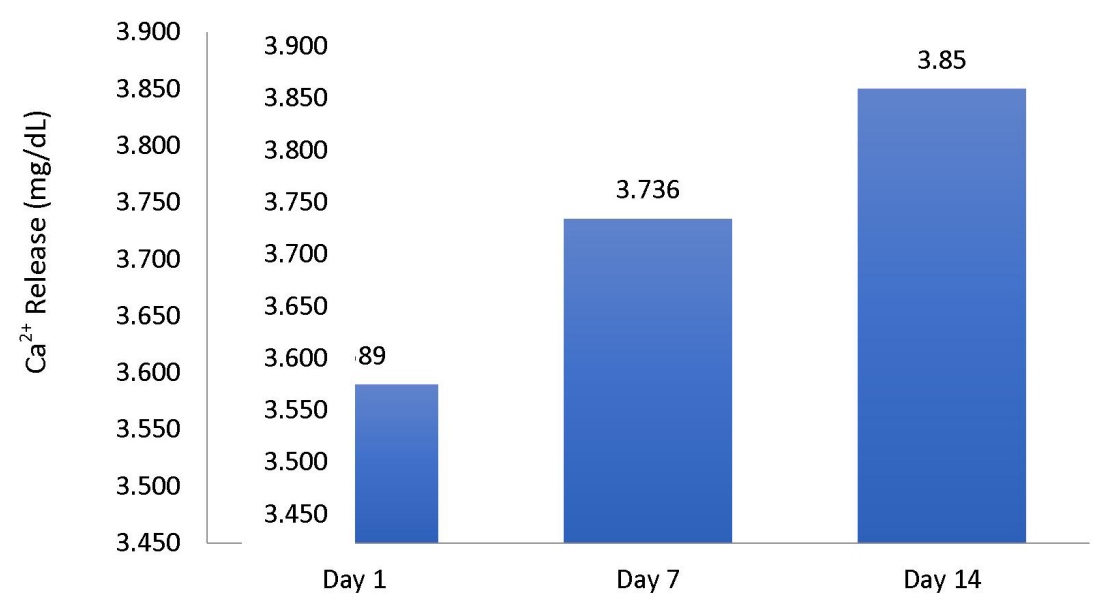

Figure 2 Comparison of $\mathrm{Ca}^{2+}$ release in $\mathrm{Ca}(\mathrm{OH})_{2}$ prototype of days 1,7 and 14

$\mathrm{Ca}^{2+}$ donor to support mineralization by apatite formation. Solvents play a role in determining the speed of dissociation or the release of $\mathrm{Ca}^{2+}$. Distilled water has neutral $\mathrm{pH}$ and low viscosity, it is commonly used for $\mathrm{Ca}(\mathrm{OH})_{2}$ paste. As this study used only distilled water, when $\mathrm{Ca}(\mathrm{OH})_{2}$ powder is dissolved with distilled water, it will rapidly decompose and becomes easily soluble, causing rapid release of $\mathrm{Ca}^{2+}$ and increases when the immersion time is longer. The viscosity of the solvent vehicle affects the release of $\mathrm{Ca}^{2+}$, distilled water has low viscosity therefore they are easier to dissolve an ingredient, so the $\mathrm{Ca}^{2+}$ release rapidly. ${ }^{16,17,22}$ This is consistent with the previous research by Grover, that $\mathrm{Ca}(\mathrm{OH})_{2}$ dissolved by distilled water showed higher ionic liberation compared to other solvent used (propylene glycol, chitosan and gutta percha points impregnated with $\mathrm{Ca}(\mathrm{OH})_{2}$ on day 1 , while the highest yield using distilled water occurred on day 14 and lowest on day 1, they gradually decreased over 15 days to 30 days of observation. ${ }^{16}$
In line with the results of our study that the $\mathrm{Ca}^{2+}$ rate increased over time from day 1,7 to the last day of observation on day 14 . Another study by Misra also observed an increase of $\mathrm{Ca}^{2+}$ rate of $\mathrm{Ca}(\mathrm{OH})_{2}$ in double distilled water from day 1 to day 2 and day 7 , however it then declined in day 15 and 30 period of observation, they concluded that the use of aqueous vehicle for $\mathrm{Ca}(\mathrm{OH})_{2}$ resulted in a rapid initial ionic dissociation which will decreased consequently. ${ }^{17}$

Several factors can affect the release of $\mathrm{Ca}^{2+}$ namely, solvent, viscosity, particle size, the ratio of powder to liquid and contamination. . $^{13,16,18}$ Viscosity of a material affects the release of $\mathrm{Ca}^{2+}$, a low viscosity vehicle will dissociate the $\mathrm{Ca}^{2+}$ and $\mathrm{OH}^{-}$ions faster because they will have less inner particle interaction, but not as stable as a viscous solvent. ${ }^{17}$ Short period of observation is one of the limitation of our present study, hence the trend of $\mathrm{Ca}^{2+}$ ions after 14 days was not recorded. However, the vast release of ions usually will eventually be tapered down in longer period observations, leaving undissolved particles. Therefore addition of other substances or the use of viscous solvents to $\mathrm{Ca}(\mathrm{OH})_{2}$, paste will enhance its bio-availability to release $\mathrm{Ca}^{2+}$ as well of $\mathrm{OH}^{-}$, because it reduces the dispersion of the $\mathrm{Ca}(\mathrm{OH})_{2}$ due to its molecular weight. ${ }^{17,19-23}$ This might improve its clinical efficiency since it can stay longer in the root canal with stable antibacterial action therefore need less appointments time during treatment. ${ }^{21}$ Smaller particle size might also enhanced the particle dissolution and reduce the number of residual unreacted particle, it will also allow the $\mathrm{Ca}(\mathrm{OH})_{2}$ to penetrate deeper to the dentinal tubules and improve it antimicrobial activity.

\section{Conclusion}

The $\mathrm{Ca}^{2+}$ release rate of the $\mathrm{Ca}(\mathrm{OH})_{2}$ prototype gradually increased from day 1 to 14 days of immersion.

\section{Acknowledgment}

The authors are grateful to Lembaga Penelitian dan Pengabdian Masyarakat (LPPM) Universitas Jenderal Achmad Yani, Indonesia in collaboration with Faculty of Dentistry, Universitas Padjadjaran, Indonesia for supporting this study and also to the Ministry of Research, Technology and Higher Education of the Republic of Indonesia for funding this research under scheme of Penelitian Dasar Unggulan Perguruan Tinggi (PDUPT) in 2019.

\section{Conflict of Interest}

The authors report no conflict of interest. 


\section{References}

1. Fulzele P, Baliga S, Thosar N, et al. Evaluation of calcium ion, hydroxyl ion release and $\mathrm{pH}$ levels in various calcium hydroxide based intracanal medicaments: An in vitro study. Contemp Clin Dentist 2011;2: 291-295.

2. Hargreaves KM, Berman LH. Cohen pathway of the pulp. 10th ed. St Louis United Kingdom: Elsevier; 2016. p. 459.

3. Kawashima N, Wadachi R, Suda H, et al. Root canal medicaments. J International Dental 2009;59: 5-11.

4. Kim D, Kim E. Antimicrobial effect of calcium hydroxide as an intracanal medicament in root canal treatment: a literature review-part I. in vitro studies, Restor. Dent Endod 2014;39: 241-252.

5. Moazami F, Sahebi S, Jamshidi D, et al. The long-term effect of calcium hydroxide, calcium-enriched mixture cement and mineral trioxide aggregate on dentin strength. J Iranian Endodontic 2014;9: 185-189.

6. Zahid S, Qadir S, Saeed A, et al. The influence of moisture on the setting time of the latest commercially available calcium hydroxide cements; a clear guideline for the dentist. Pakistan Oral \& Dent J 2016;36: 691-696.

7. Komabayashi T, D'Souza RN, Dechow PC, et al. Particle size and shape of calcium hydroxide. JOE 2009;35: 284-287.

8. Sidiqa AN. Biomimetics in dental materials. J Material Kedokteran Gigi 2013;2: 1-8. (In Indonesian)

9. Zakaria MN, Sidiqa AN, Artilia I, et al. Synthesis and characterization of calcium hydroxide from indonesian limestone as endodontic intracanal medicament. KEM 2018;782: 268-272.

10. Chaudhari WA, Jain RJ, Jadhav SK, et al. Calcium ion release from four different lightcured calcium hydroxide cements. Endodontol 2016;28: 114-118.

11. Srinivas S, Jibhkate NG, Baranwal R, et al. Propylene glycol: a new alternative for an intracanal medicament. J Int Oral Health 2016;8: 611-614.

12. Zakaria MN. Save the pulp is the essential issues on pulp capping treatment, J Dentomaxillofac Sci 2016;1: 73-76.

13. Komabayashi T, D'Souza RN, Dechow PC, et al. Particle size and shape of calcium hydroxide. JOE 2009;35: 284-287.

14. Carré E, Pérot J, Jauzein V, et al. Estimation of water quality by UV/Vis spectrometry in the framework of treated wastewater reuse. Water Sci Technol 2017;76: 633-641.
15. Behera S, Ghanty S, Ahmad F, et al. UV-Visible spectrophotometric method development and validation of assay of paracetamol tablet formulation. J Int Chemical Analytic Sci 2012;3: 1656-1661.

16. Grover C, Shetty N. Evaluation of calcium ion release and change in $\mathrm{pH}$ on combining calcium hydroxide with different vehicles. Contemp Clin Dentist 2014;5: 434-439.

17. Misra P, Bains R, Loomba K, et al. Measurement of ph and calcium ions release from different calcium hydroxide pastes at different intervals of time: atomic spectrophotometric analysis. J Oral Biol Craniofas Res 2017;7: 36-41.

18. Zakaria MN, Cahyanto A, El-Ghannam A. Calcium release and physical properties of modified carbonate apatite cement as pulp capping agent in dental application. Biomater Res 2018;22: 35.

19. Jain A, Bhadoria K, Hada HS. Spectrophotometric evaluation of calcium ion release from different calcium hydroxide preparations: An in-vitro study. J Oral Res 2017;6: 61-63.

20. Athanassiadis B, Walsh LJ. Aspects of solvent chemistry for calcium hydroxide medicaments. Materials (Basel) 2017;23: 10.

21. Teoh Y, Athanassiadis B, Walsh LJ. The influence of aqueous and PEG 400 solvent vehicles on hydroxyl ion release from calcium hydroxide medicaments. Int DentistAfrican Ed 2017;7: 30-40.

22. Fava LRG, Saunders WP. Calcium hydroxide pastes: classification and clinical indications. Int Endod J 1999;32: 257-282.

23. Nugroho JJ. One versus two visits of endodontic treatment on teeth with apical periodontitis. J Dentomaxillofac Sci 2016;1: 77-79.

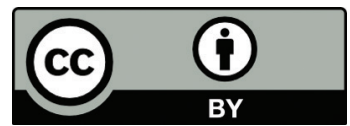

This work is licensed under a Creative Commons Attribution 